\title{
Our coastal areas at risk: what can we do about it?
}

\author{
CHUA THIA-ENG
}

Partnerships in Environmental Management for the Seas of East Asia, DENR Compound, Visayas Ave, Diliman 1100, Quezon City, Philippines (chuate@pemsea.org)

SUMMARY: The coastal systems traditionally play important ecological and socioeconomic functions by providing goods and services, contributing to food security, rural stability, coastal urbanization and economic prosperity. These functions, however, are being impaired by indiscriminate human activities. A paradigm shift in the way of managing the coastal area is recommended by moving from single to integrated management and coordinated approach, from centrally command-and-control system to people participation and from two-tiered to multi-tiered approach. A regional environmental governance, as embodied in the Environmental Strategy for the Seas of East Asia, serves as a guide-post for effective environmental management.

\section{KEY WORDS: integrated coastal management, environmental strategy, coastal/marine policy, environment/resource governance}

\section{INTRODUCTION}

The coast is commonly understood as the interface between land and sea, but our concerns and interests are concentrated on the part of the coast where human activities are closely linked with both land and marine environment. The term "coastal areas at risk" denotes the part of the coastal system that might lose its functional integrity in generating resources and services.

The coastal area, primarily consists of a narrow strip of coastal lowland and adjacent water, is continuously influenced by the combined impacts of the land and the sea. It is vulnerable to natural disturbances and environmental changes occurring at the adjacent watershed areas and the open sea.

The coastal areas around the world are extensively utilized particularly in the East Asian Sea region where at least 60 per cent of the 1.9 billion people reside and a large part of the economic activities are located.

\section{WHAT DO OUR COASTS DO FOR US?}

Traditionally, our coastal systems play important ecological and socioeconomic functions by providing us goods and services. The rich ecosystems in the coastal area generate fishery and other marine products for food, medicine and chemicals. They protect lives and properties against storm surges, typhoons, cyclones and floods as well as provide livelihoods and income for many of the coastal inhabitants.

The coastal area is the center of economic activities contributing a large part of the national gross domestic product. Nine out of the 20 world international ports are located in East Asia amongst thousands of small- and medium-sized terminals and harbors. Most major cities are located in the coastal area of which eight are megacities having population of more than ten million. The region is noted for its maritime trade and heavy shipping traffic. Many oil deposits are located in the near shore of the South China Sea, the Bohai Sea and the Indonesian Seas. The coastal fisheries contribute a major part of the 35 million tonnes of fish landed annually (FAO, 2000). Many of the coastal waters are also being used for mariculture (Hongskul, 1999).

Of the five large marine ecosystems, four are located in the tropical Southeast Asia. Species diversity in these waters is higher than that of the Great Barrier Reef or the Caribbean Seas, making the region the center for marine biodiversity. More than a third of the world's coral reefs and mangroves are located in the Southeast Asian region. Every year, tens of millions of tourists are attracted to the diversity of marine life, beautiful sandy beaches and landscapes. Tourism is thus amongst the top national revenue earners of the region. 
In essence, the coastal area plays a vital role in food security, rural stability, urbanization and economic prosperity of many coastal nations in the region.

\section{WHAT HAVE WE DONE TO OUR COASTS?}

Due to coastal urbanization and intense economic development, severe conflicts result from multiple use and competition for the limited land and sea resources. The competition for natural resources and marine space is expected to become greater with the advent of realignment of regional economy and globalization of maritime trades. Continued development modifies the coasts as land conversion, dredging and water pollution become synonymous to progress.

The state of coastal environment is deteriorating habitats are being destroyed at a rapid rate; more than half of the mangroves and coral reefs are being degraded; most sea grass beds are gone because of sedimentation or due to the impacts of pollution; the coastal waters are heavily contaminated with human sewage and industrial effluents; pollution hotspots in the region are increasing in numbers, and heavy metal contamination has been reported in increasing number of areas. All these have serious impacts on the marine life and resources of the open sea.

Pollution is more severe as one gets closer to the shore. River basins and watersheds are also not spared as a result of industrialization and urbanization. Dam construction along tributaries and rivers for irrigation and electricity generation also affect water supply downstream resulting to saltwater intrusion and sediment budget.

\section{WHAT ARE THE SOCIOECONOMIC IMPLICATIONS?}

It is apparent that many of these adverse impacts are seriously threatening the market and non-market values of the ecosystems. The socioeconomic loss of the ecosystems is not easy to measure due to lack of information on environmental accounting and natural resource evaluation techniques. In recent years, researchers have been able to provide a general estimate of the values of different biomes (Table 1). This figure may not be absolutely accurate but it provides a guide for policymakers and resource managers in the decision making process. For example, mangroves used to be considered as wastelands before. Today, its annual value is estimated to be US $\$ 10,000$ per hectare. If such value was known in the early $70 \mathrm{~s}$, the use of mangroves for shrimp farming might have been discouraged. The same also applies to seagrass beds and coral reefs which are valued at US $\$ 19,000$ and US $\$ 6,000$ per hectare per year, respectively.

Table 1. Estimated mean value of some marine biomes (Costanza et al., 1998).

\begin{tabular}{|l|c|}
\hline \multicolumn{1}{|c|}{ Biomes } & Value (USD/ha/yr) \\
\hline Estuaries & 22,832 \\
Seagrass/algal beds & 19,004 \\
Mangrove/tidal marsh & 9,990 \\
Coral reef & 6,075 \\
Continental shelf & 804 \\
Open ocean & 252 \\
\hline
\end{tabular}

How much the region has lost in terms of the values of its biomes is yet to be determined. For coral reefs in Southeast Asia, the annual value of coral reefs has been estimated at US\$112. 5 million (Ruitenbeek, 1999) while the estimated global value of goods and services sourced from different ecosystems averages US\$ 33 trillion (Costanza et al., 1998) and ocean services worldwide is estimated at US\$23 trillion a year (GESAMP, 2001).

The socioeconomic implications due to oil spills, fish kills, toxic algal blooms, and diseases are rather obvious. Less than 10 per cent of human sewage are treated while a large amount of industrial effluents enters the coastal waters. The direct loss from 256 red tide occurrences in China from 1972-1994 was estimated at US\$ 602 million (Anonymous, 1998). Much of these occurrences were blamed on the hundreds of tons of wastewater discharged into the coastal waters.

A recent UN report states that "respiratory and intestinal diseases and infections among bathers rise steadily. Bathers are at risk even in lightly contaminated waters that meet the pollution standards laid by EU and the USEPA. Bathing in polluted seas causes some 250 million cases of gastroenteritis and upper respiratory disease every year" (GESAMP, 2001). Many of the coastal waters in the region are certainly polluted due to the large amount of untreated sewage entering the water system. In Manila Bay, for example, the mean risk quotient in terms of public health risk is high throughout 
the bay, making the bay not fit for any form of public recreation.

The cost of remedial actions could be very high. To remove 40 per cent of the existing pollution load entering the Bohai Sea would require at least US\$2.1 billion in terms of infrastructure. World Bank estimates that the remedial action might cost $0.8-1 \%$ of the GDP.

\section{WHAT CAN WE DO ABOUT IT?}

It is apparent that most of the resource depletion and environmental degradation problems identified decades ago have not been resolved. In fact, they have gotten worse. A paradigm shift in the way of managing the coastal areas is certainly needed by moving from single sector to muti-sector management, from less/absence of coordination to more integrated and coordinated approach, from central to local government, from command and control system to people participation. Policy reforms and local capacity strengthening are essential.

\section{Integrated management}

Natural resource and environmental governance require coordinated efforts from all concerned sectors of the economy so that policy and management functions are effectively integrated and enforced. Coordination and integration are needed to strengthen sector management.

The UN Conference on Environment and Development (UNCED) recommended integrated coastal management (ICM) as a feasible approach for sustainable development instead of the traditional single sector approach of "command and control." In the last three decades, 380 ICM projects were initiated worldwide and a fair number were conducted in the East Asian Seas region. Many of these donor driven efforts, however, are not well coordinated and most failed to reach the implementation stage or able to sustain (Chua, in press).

Nevertheless, some projects have been successful. The ICM programs at Xiamen, China and Batangas Bay, Philippines, were able to establish the much-needed coordinating mechanisms to implement a set of activities designed through the ICM program. In Xiamen, environmental improvements have brought socioeconomic benefits and received strong citizens support. ICM, in this case, has been proven to be effective at the local level.

\section{National Coastal/ Marine Policy}

Several countries in the region have made significant progress in strengthening coastal and marine resource governance, maritime safety and environment sustainability. They have developed or initiated national coastal/marine policy in recognition of the increasing maritime conflicts, multiple-use conflicts at the coastal areas, need for interagency coordination and sustainable use of the vast marine potential. Indonesia, the Philippines, RO Korea, Japan, China, Thailand and Malaysia are moving towards this direction (Batongbacal, 2000; Jiao et al., 2000; Nakahara, 2000; Mohd. Nizam, 2000). In fact, RO Korea is the first Asian nation to enact a Coastal Management Act (Lee, 2000). Indonesia, Philippines and Thailand on the other hand have explicit legislations that decentralize authority to the local government for the management of natural resources and the environment. Finally, policy reforms and change in administrative structure in ROK, Indonesia and Japan through strengthening the integration of ocean related sectors are marked improvements towards integrated ocean governance.

\section{Transboundary issues}

Transboundary issues arising from the exploitation and management of shared fishery stocks, management of shared ecosystems, impacts of pollution, climate change, biodiversity, use and management of international waters and archipelagic sea-lanes require regional and international cooperation. There are existing multilateral instruments to address each of the major issues such as the UN Law of the Seas, MARPOL, Agenda 21, GPA, UNFCCC, Biodiversity, CITES and the Code of Conduct for Responsible Fisheries. Unfortunately, many of these instruments are not being effectively implemented particularly in many developing and even developed nations.

Environmental issues of national concern have always been considered as the sole responsibility of nations and respective sectors, while transboundary issues as the primary concern of the United Nations. However, globalization and realignment of regional economy particularly in East Asia, have rendered this two-tiered and sectoral approach ineffective. A multitiered and multisectoral integrated approach at the regional, national and local levels is necessary to resolve the environmental problems in the region. 


\section{Environmental Strategy for the Seas of East Asia}

The Environmental Strategy is the most recent regional initiative of the stakeholders of the region. This document was developed through extensive consultation with experts, governments and other stakeholders. The purpose is to develop a comprehensive and holistic approach in environmental and natural resource governance of the Seas of East Asia, through a regional collaborative framework, strategies and action programs for addressing issues and problems towards achieving a shared vision of the region (Fig. 1). Effective governance is achieved through:

a) A functional framework for intergovernmental collaboration in addressing global/regional environmental concerns; strengthening synergies and linkages amongst UN and international agencies; and encouraging active participation from the private sector, NGOs, academe, communities and other members of the civil society; enhancing the synergistic relationship among international agreements; strengthening partnerships among governments, intergovernmental bodies and other sectors; and establishing multi-tiered arrangements for the cost-effective implementation of these multilateral instruments, and

c) Assessment and documentation of changes arising from implementation of the Environmental Strategy, and periodic refinement through scientific research, integrated environmental monitoring and South-South cooperation.

\section{CONCLUSION}

Problems confronting the sustainable use of the coastal areas are complicated. Whilst our coasts continue to degrade, there is increasing awareness of the consequences of losing this important natural asset. Global concerns of the coastal and marine environment

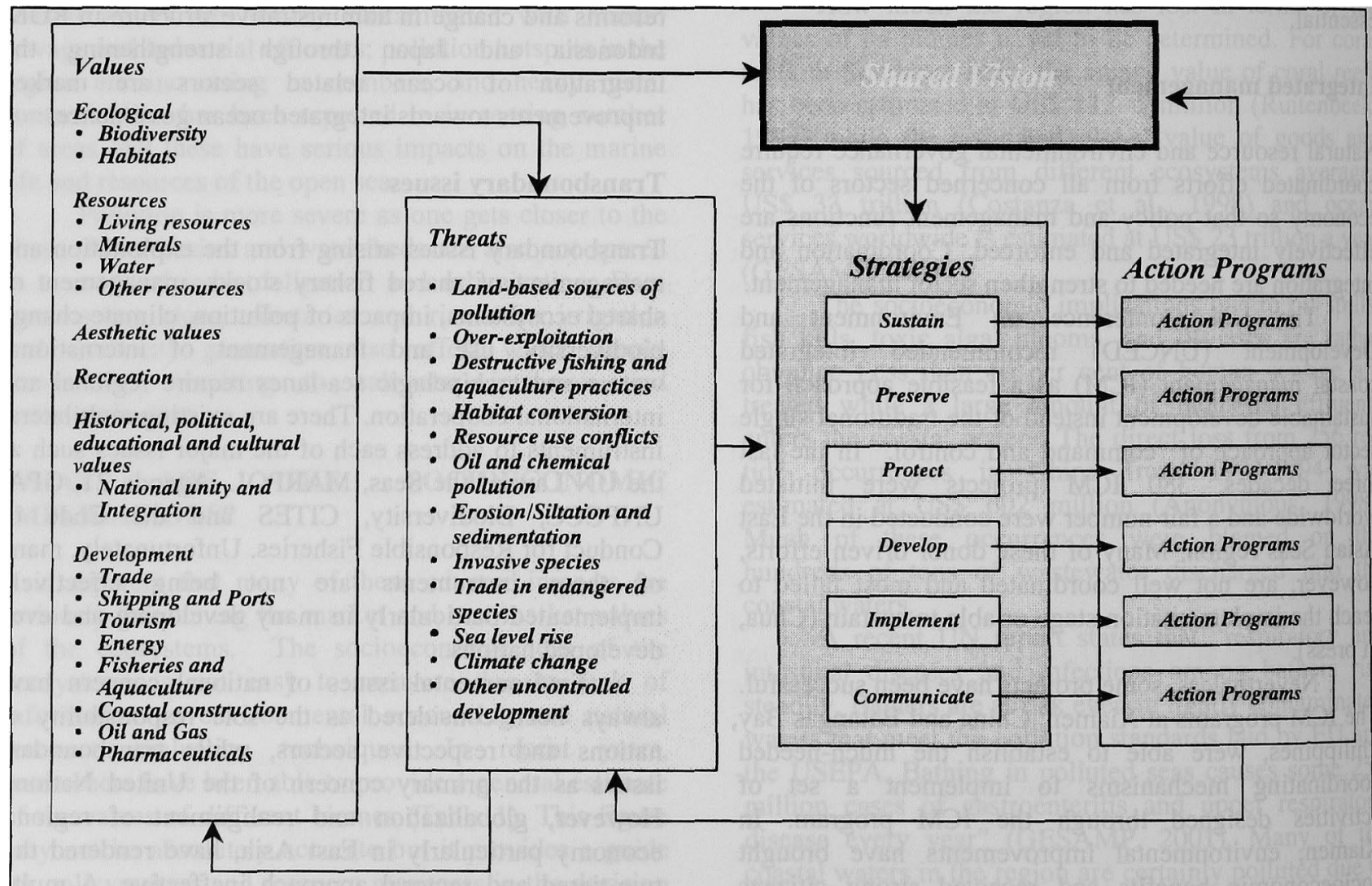

Fig. 2. A strategic approach to achieving a shared vision.

b) An integrated approach for implementing multilateral environmental instruments at the regional level by have resulted in donor-driven initiatives to explore ways and means of arresting the continuing decline of coastal 
environmental quality. Already, not less than US\$ 100 million have been invested on such initiatives per year in the last decade. Donor investments on coastal and marine management in the Philippines alone are in the order of US\$ 20 million/yr for the last 10 years. Unfortunately, the lack of coordinated efforts turned many of the external initiatives less effective than expected.

Coordination between donors, countries and agencies as well as the level of governance is needed. Whilst institutional arrangements are the desired outcomes, the political will for sustainable development and a cleaner environment is certainly a prerequisite. Perhaps the usual perception of "We save the coasts" should be changed to "The coasts save us."

\section{REFERENCE}

1. Anonymous. Red tides has limited impact, 1998, http://www.chinaenvironment.com/english/news/101198tide2. html.

2. Batongbacal, J.L. Re-inventing the national marine policy of the Philippines. Tropical Coasts, 2000, 7: 32-38.

3. Chua, T.E. An analysis of the application of integrated coastal management - linking local and global environmental concerns, in press.

4. Costanza, R, D'Arge, R., De Groot, R., Farber, S, Grasso, M., Hannon, B., Limburg, K, Naeem, S, O'Neill, R.V., Paruelo, J., Raskin, R., Sutton, $P$ and Van den Belt, M. The value of the world's ecosystem services and natural capital. Ecological Economics, 1998, 387: 253-260.

5. FA0. The state of the world fisheries and aquaculture. Food and Agriculture Organization of the United Nations, Rome, $2000,144 \mathrm{p}$.

6. GESAMP (IMO/FAO/UNESCO-IOC/WMO/WHO/LAEA/UN/ UNEP Group of Experts on the Scientific Aspects of Marine Environmental Protection). A sea of troubles. Rep. Stud. GESAMP No. 70, 2001, 35 p.

7. Hongskul, V. Into the next millennium: fishery perspective. RAP Working Paper Series 1/3, Food and Agriculture Organization of the United Nations, Regional Office for Asia and the Pacific, Bangkok, 1999, 43 p.

8. Jiao, Y., Ruan, C. and Yu, H. The new marine environmental protection law of the People's Republic of China. Tropical Coasts, 2000, 7: 24-31.

9. Lee, J. Evolution of national coastal policy in Korea. Tropical Coasts, 2000, 7: 12-23.
10. Mohd. Nizam bin Basiron. The development of coastal zone management policy for Malaysia. Tropical Coasts, 2000, 7: 44-51.

11. Nakahara, H. Japan's coastal and ocean policy in the beginning of the $21^{\text {st }}$ century, Tropical Coasts, 2000, 7: 6670 .

12. Ruitenbeek, J. Blue pricing of undersea traseures - needs and opportunities for environmental economics research on coral reef management in Southeast Asia. Paper presented to the $12^{\text {th }}$ Biannual Workshop of the Environmental Economics Program for Southeast Asia, Singapore 11-14 May, IDRC, Singapore. 